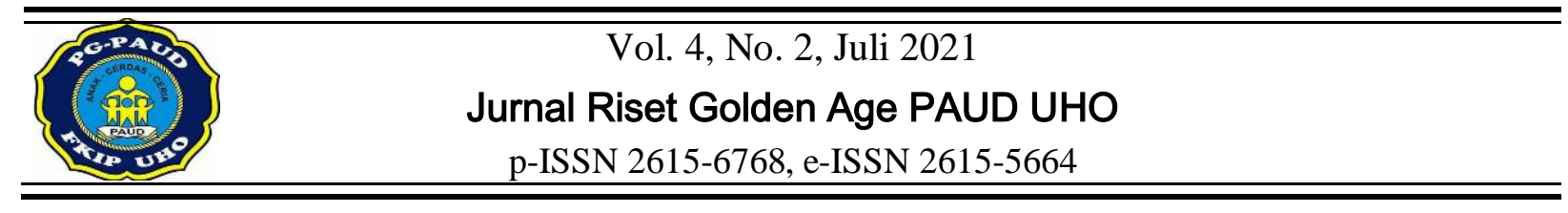

\title{
PENERAPAN KEGIATAN MEMBUAT BONEKA UNTUK MENINGKATKAN KEMAMPUAN MOTORIK HALUS
}

\author{
Lilis Rahmat ${ }^{\text {1) }}$, Salwiah ${ }^{1)}$, Muhamad Safiuddin Saranani ${ }^{1)}$ \\ ${ }^{1}$ Jurusan PG-PAUD, Universitas Halu Oleo. Jln. H.E.A Mokodompit, Kendari 93232, Indonesia. \\ *Email: lilis.rahmat@gmail.com
}

\begin{abstract}
Abstrak
Penelitian ini bertujuan untuk meningkatkan kemampuan motorik halus anak melalui kegiatan membuat boneka di kelompok B4 TK Tunas Makarti Kendari. Subjek dalam penelitian ini adalah guru dan anak didik yang berjumlah 15 orang anak dengan rentang usia 5-6 tahun. Berdasarkan analisis data aktivitas mengajar guru pada siklus I diperoleh persentase ketercapaian 79\%, aktivitas belajar anak pada siklus I diperoleh persentase ketercapaian sebesar 79\% dan hasil belajar anak diperoleh persentase ketercapaian sebesar 73\%. Siklus II persentase ketercapaian aktivitas mengajar guru 93\%, aktivitas belajar anak pada siklus II diperoleh persentase ketercapain sebesar 93\% dan hasil belajar anak pada siklus II diperoleh persentase ketercapaian sebesar 87\%. Berdasarkan hasil analisis data dalam penelitian ini dapat disimpulkan bahwa dengan pembelajaran menggunakan kegiatan membuat boneka kemampuan motorik halus anak di kelompok B TK Tunas Makarti Kendari dapat ditingkatkan.
\end{abstract}

Kata kunci: anak usia dini, kemampuan motorik halus, membuat boneka.

\section{APPLICATION OF DOLL-MAKING ACTIVITIES TO IMPROVE FINE MOTOR ABILITY}

\begin{abstract}
This study aims to improve children's fine motor skills through the activity of making dolls in group B4 TK Tunas Makarti Kendari. The subjects in this study were teachers and students, totaling 15 children with an age range of 5-6 years. Based on the data analysis of the teacher's teaching activities in the first cycle, the achievement percentage was 79\%, the children's learning activities in the first cycle obtained the achievement percentage of $79 \%$ and the children's learning outcomes obtained the achievement percentage of 73\%. Cycle II the percentage of achievement of teacher teaching activities is 93\%, children's learning activities in cycle II are obtained by the percentage of achievement of $93 \%$ and student learning outcomes in cycle II are obtained by the percentage of achievement of $87 \%$. Based on the results of data analysis in this study, it can be concluded that by learning to use the activity of making dolls, the fine motor skills of children in group B of TK Tunas Makarti Kendari can be improved.
\end{abstract}

Keywords: early childhood, fine motor skills, making dolls.

\section{PENDAHULUAN}

Pendidikan anak usia dini berfungsi membantu dan mengarahkan proses tumbuh kembang anak agar lebih terarah dan terpadu, pendidikan anak usia dini secara khusu bukan bertujuan memberikan anak pengetahuan kognitif (kecerdasan intelek) tetapi mempersiapkan mental dan fisik anak untuk mengenal dunia sekitarnya secara lebih adaptive (bersahabat). Sifat pendidikan anak usia dini lebih familier (kekeluargaan), komunikatif (menyenangkan) dan lebih utama adalah persuative (seruan/ajakan) (Widianingsih, 2012). Pada anak usia dini terdapat aspek-aspek yang perlu dikembangkan diantaranya aspek kognitif, bahasa, nilai moral dan agama, sosial dan emosional, fisik/motorik dan seni. Dari aspek-aspek tersebut aspek fisik/motorik dan seni merupakan salah satu aspek yang perlu dikembangkan pada anak usia dini. Menurut Damayanti \& Nurjannah (Romlah, 2017) perkembangan motorik adalah proses tumbuh kembang kemampuan gerak anak yang pada dasarnya perkembangan ini sejalan dengan 
kematangan saraf, otot anak ataupun kemampuan kognitifnya.

Aspek motorik dibagi menjadi motorik halus dan motorik kasar, keduanya perlu dikembangkan agar anak mampu mengendalikan gerakan tubuhnya secara efektif. Menurut (Kusumaningtyas, 2016) latihan terhadap motorik kasar dan halus perlu dilakukan untuk meningkatkan kemampuan anak dalam mengendalikan gerakan tubuh dan anggotanya secara efektif, yang mencakup kegiatan untuk melatih koordinasi mata dan tangan, melatih konsentrasi, koordinasi indra dan anggota tubuh, melatih kepercayaan diri, keseimbangan tubuh, keberanian, kelenturan dan kekuatan otot, serta melatih kesiapan untuk menulis. Menurut (Nurlila \& Fua, 2015) motorik kasar merupakan gerakan tubuh yang menggunakan otot-otot besar yang dipengaruhi oleh kematangan anak itu sendiri, seperti merangkak, berjalan, berlari, melompat dan berenang. Adapun motorik halus merupakan gerakan yang menggunakan otot-otot kecil yang memerlukan koordinasi yang cermat dan tidak memerlukan banyak tenaga. Kemudian menurut Sumartini (Pura \& Asnawati, 2019) mengatakan bahwa perkembangan motorik halus merupakan perkembangan gerakan anak yang menggunakan otot kecil atau sebagain anggota tubuh tertentung yang dipengaruhi oleh kesempatan anak untuk belajar dan berlatih.

Berdasarkan pendapat di atas dapat disimpulkan bahwa motorik halus merupakan gerakan yang hanya melibatkan bagian-bagian tubuh tertentu dan dilakukan oleh otot-otot kecil, seperti menggunakan jari-jemari tangan, dan gerakan pergelangan tangan yang tepat. Untuk itu motorik halus pada anak usia dini perlu dikembangkan dengan tujuan dapat mendukung perkembangan aspek lainnya, seperti kognitif dan bahasa serta sosial karena pada hakekatnya setiap pengembangan tidak dapat terpisah satu sama lain. Peningkatan keterampilan motorik halus di TK dapat dilakukan melalui berbagai kegiatan pembelajaran yang melatih kemampuan koordinasi mata dan tangan.

Berdasarkan hasil observasi awal yang dilakukan peneliti di Kelompok B4 TK Tunas Makarti Kendari diperoleh informasi bahwa anak-anak pada umumnya masih membutuhkan media yang baru untuk meningkatkan kemampuan motorik halus mereka agar perkembangannya semakin maksimal. Perkembangan motorik halus anak TK Tunas Makarti Kendari di kelompok B4 sudah mulai berkembang dengan baik namun masih dilakukan inovasi dalam kegiatan pembelajaran sehingga kemampuan motorik halus anak dapat ditingkatkan secara maksimal. Adapun data hasil observasi awal anak kelompok B1 adalah sebagai berikut: terdapat 3 orang anak yang mendapat nilai bintang $(* * * *)$ dengan persentase $20 \%$, terdapat 4 orang anak didik yang mendapat nilai bintang (***) dengan persentase $27 \%$, terdapat 6 orang anak didik yang mendapat nilai bintang $(* *)$ dengan persentase $47 \%$, dan terdapat 2 orang anak didik yang mendapat nilai bintang (*) dengan persentase $6 \%$.

Bertitik tolak pada permasalah di atas, terdapat berbagai macam kegiatan yang dapat dilakukan dalam pembelajaran dengan tujuan dapat meningkatkan kemampuan motorik halus anak usia dini. Pembalajaran yang menggunakan kegiatan kolase dan membuat boneka merupakan dua diantara berbagai kegiatan yang dapat dilakukan kan untuk meningkatkan motorik halus anak. Seperti pada penelitian yang dilakukan oleh (Darmiatun \& Mayar, 2020) melalui kegiatan kolase menggunanakan bahan bekas kemampuan motorik halus anak dapat ditingkatkan. Kemudian penelitian yang dilakukan oleh (Nurhasanah, Malik \& Alaby, 2019) menunjukkan adanya peningkatan motorik halus anak melalui permainan membuat boneka kerta. Untuk itu, peneliti dalam penelitian akan menggunakan kegiatan membuat boneka dalam upaya meningkatkan kemampuan motorik halus anak. Hal ini dilakukan karena berdasarkan tinjauan yang dilakukan peneliti ditemukan bahwa penggunaan kolasa dalam pembelajaran sudah banyak dilakukan, sedangkan kegiatan membuat boneka masih jarang dilakukan, sehingga peneliti memilih menggunakan kegiatan membuat boneka karena dinilai lebih inovatif dan dapat menarik minat anak didik untuk mengikuti kegiatan pembelajaran.

Penelitian ini bertujuan untuk meningkatkan kemampuan motorik halus anak melalui kegiatan membuat boneka di kelompok B4 TK Tunas Makarti Kendari.

\section{METODE}

Jenis penelitian yang digunakan adalah Penelitian Tindakan Kelas (PTK). Penelitian ini bertempat di kelompok B4 TK Tunas Makarti Kendari pada semester ganji 2019/2020. Subjek dalam penelitian ini adalah guru dan anak didik berjumlah 15 orang anak yang terdiri dari 7 orang anak laki-laki dan 8 orang anak perempuan. 
Adapun faktor-faktor yang akan diteliti dan diamani dalam penelitian ini adalah; a) faktor guru dan aktivitas mengajar guru; b) faktor anak, aktivitas belajar anak dan hasil belajar anak dalam mengikuti kegiatan pembelajaran; c) hasil belajar anak.

Teknik pengumpulan data dalam penelitian ini dilakukan dengan cara observasi, wawanacra dan dokumentasi. Observasi dilakukan untuk mengamati aktivitas guru dan anak didik dalam melakukan kegiatan pembelajaran dikelas. Wawancara dilakukan untuk memperoleh informasi yang akan dijadikan sebagai tolak ukur penilaian keberhasilan proses pembelajaran sebelum dan sesudah penerapan pembelajaran menggunakan media membuat boneka untuk meningkatkan kemampuan mengenal motorik. Dokumentasi dilakukan untuk memperoleh data-data berupa catatan yang diberikan keterangan atau bukti yang berkaitan dengan proses pengumpulan data dan berupa foto-foto selama proses penelitian dilakukan dilapangan.

Tehnik analisis data yang digunakan adalah dengan menggunakan analisis deskriptif. Metode analisis deskriptif adalah metode yang menjelaskan atau menggambarkan fenomena penelitian secara objektif. Analisis data merupakan cara yang dilakukan untuk mengetahui keefektifan suatu metode dalam kegiatan pembelajaran. Pengelolaan data dalam penelitian ini disesuaikan dengan teknik penilaian di TK yaitu dengan menggunakan tanda sebagai berikut: * = belum berkembang $(\mathrm{BB}), * *=$ mulai berkembang $(\mathrm{MB}), * * *=$ berkembang sesuai harapan (BSH), dan $* * * *=$ berkembang sangat baik (BSB), (Angraeni, Arvyaty, \& Salim, 2018).

Tabel 1. Kategori Keberhasilan Klasikal

\begin{tabular}{ccc}
\hline Persentase & Kategori & Simbol \\
\hline $95 \%-100 \%$ & $\mathrm{BSB}$ & $* * * *$ \\
$85 \%-94 \%$ & $\mathrm{BSH}$ & $* * *$ \\
$75 \%-84 \%$ & $\mathrm{MB}$ & $* *$ \\
$<75 \%$ & $\mathrm{BB}$ & $*$ \\
\hline
\end{tabular}

Indikator keberhasilan dalam penelitian ini adalah indikator proses dan indikator hasil (nilai). Dari segi proses, tindakan dikatakan berhasil apabila hasil observasi terhadap guru dan anak telah mencapai presentase minimal $85 \%$ sesuai dengan skenario kegiatan pembelajaran, sedangkan dari segi hasil, apabila $85 \%$ anak memperoleh nilai berkembang sesuai harapan (BSH) atau dengan simbol $* * *$ dan berkembang sangat baik (BSB) atau dengan simbol ****, maka dapat dikatakan peningkatan kemampuan motorik halus dengan media membuat boneka telah berhasil.

\section{HASIL DAN PEMBAHASAN}

Sebelum kegiatan penelitian ini dilaksanakan, peneliti terlebih dahulu melakukan diskusi dengan guru kelompok B4 TK Tunas Makarti Kendari. Berdasarkan hasil observasi dan wawancara yang dilakukan di peroleh infomasi bahwa kemampuan motoric halus anak di kelompok B4 TK sudah mulai berkembang dengan baik namun, masih perlu dilakukan meningkatan dengan media pembelajaran yang baru atau kegiatan baru untuk meningkatkan kemampuan motorik halus anak secara maksimal. Untuk itu peneliti berusahan merancang suatu kegiatan pembelajaran unik dan menarik dengan tujuan dapat meningkatkan kemampuan motorik halus anak melaui kegiatan membuat boneka.

Penelitian ini sesuai dengan jadwal yang telah disusun sebelumnya, yaitu dilaksanakan sebanyak dua siklus kegiatan pembelajaran yang masing-masing siklus terdiri dari empat kali pertemuan dengan indikator meningkatkan kemampuan motorik halus anak melalui kegiatan membuat boneka.

Pelaksanaan tindakan siklus I pertemuan I dilaksanakan dengan kegiatan inti guru mengatur anak-anak untuk berbaris dengan rapi dan sesuai dengan kelas masing-masing serta tak lupa juga anak-anak menyanyikan beberapa lagu, kemudian mengucapkan salam dan masuk kelas secara berurut. Selanjutnya guru membuka proses pembelajaran dengan mengucapkan salam, setelah itu anak-anak bernyanyi beberapa lagu.

Sebelum memasuki proses pembelajaran anak-anak melakukan aktifitas tanya jawab bersama guru mengenai pelajaran sebelumnya. Pada kegiatan inti pertemuan I dalam meningkatkan kemampuan motorik halus anak, guru melakukan kegiatan motorik awal yang biasa dilakukan pada tiap paginya dalam kelas. Guru menjelaskan tentang tema yang dibawakan yaitu tema binatang/binatang yang hidup di laut/ikan. Guru mengadakan tanya jawab akan tema yang telah dijelaskan kepada anak-anak. Setelah memberikan apersepsi dan tanya jawab dengan anak, guru menjelaskan mengenai tugas yang akan dilakukan. Pertama adalah guru memperlihatkan boneka yang telah dibuatnya, guru menjelaskan langkah-langkah dalam membuat boneka, guru memberikan alat dan 
bahan pada masing-masing anak untuk membuat boneka menyerupai ikan dan guru memberikan bimbingan pada anak-anak yang masih kesusahan dalam membuat boneka.

Selanjutnyan masuk pada kegiatan akhir dimana guru mempersilahkan anak-anak untuk duduk kembali dan mengarahkan anak untuk mencuci tangan sebelum makan. Kemudian, masuk pada kegiatan makan bersama, sebelum kegiatan makan bersama dimulai guru membimbing anak untuk membaca doa sebelum makan. Setelah anak selesai makan guru membimbing anak berdoa sesudah makan dan mempersilahkan anak untuk bermain diluar ruangan. Selanjutnya, anak masuk kedalam ruangan untuk bersiap pulang, sebelum jam pelajaran ditutup, guru mengajak anak untuk membuat kesimpulan tentang kegiatan yang telah dilakukan yaitu menceritakan tentang kegiatan apa yang telah dilakukan. Setelah itu guru memberikan informasi tentang kegiatan yang akan dilakukan besok, kemudian guru mempersiapkan anak-anak untuk membaca doa keluar kelas dan doa keselamatan dunia akhirat dan lain-lain serta mengucapkan salam.

Pelaksanaan tindakan siklus I pertemuan II dilaksanakan dengan kegiatan inti guru mengatur anak-anak untuk berbaris dengan rapi dan sesuai dengan kelas masing-masing serta tak lupa juga anak-anak menyanyikan beberapa lagu, kemudian mengucapkan salam dan masuk kelas secara berurut. Selanjutnya guru membuka proses pembelajaran dengan mengucapkan salam, setelah itu anak-anak bernyanyi beberapa lagu.

Sebelum memasuki proses pembelajaran anak-anak melakukan aktifitas tanya jawab bersama guru mengenai pelajaran sebelumnya. Pada kegiatan inti pertemuan I dalam meningkatkan kemampuan motorik halus anak, guru melakukan kegiatan motorik awal yang biasa dilakukan pada tiap paginya dalam kelas. Guru menjelaskan tentang tema yang dibawakan yaitu tema binatang/binatang yang hidup di laut/bintang laut. Guru mengadakan tanya jawab akan tema yang telah dijelaskan kepada anakanak. Setelah memberikan apersepsi dan tanya jawab dengan anak, guru menjelaskan mengenai tugas yang akan dilakukan. Pertama adalah guru memperlihatkan boneka yang telah dibuatnya, guru menjelaskan langkah-langkah dalam membuat boneka, guru memberikan alat dan bahan pada masing-masing anak untuk membuat boneka menyerupai bintang laut dan guru memberikan bimbingan pada anak-anak yang masih kesusahan dalam membuat boneka.
Selanjutnyan masuk pada kegiatan akhir dimana guru mempersilahkan anak-anak untuk duduk kembali dan mengarahkan anak untuk mencuci tangan sebelum makan. Kemudian, masuk pada kegiatan makan bersama, sebelum kegiatan makan bersama dimulai guru membimbing anak untuk membaca doa sebelum makan. Setelah anak selesai makan guru membimbing anak berdoa sesudah makan dan mempersilahkan anak untuk bermain diluar ruangan. Selanjutnya, anak masuk kedalam ruangan untuk bersiap pulang, sebelum jam pelajaran ditutup, guru mengajak anak untuk membuat kesimpulan tentang kegiatan yang telah dilakukan yaitu menceritakan tentang kegiatan apa yang telah dilakukan. Setelah itu guru memberikan informasi tentang kegiatan yang akan dilakukan besok, kemudian guru mempersiapkan anak-anak untuk membaca doa keluar kelas dan doa keselamatan dunia akhirat dan lain-lain serta mengucapkan salam.

Pelaksanaan tindakan siklus I pertemuan III dilaksanakan dengan kegiatan inti guru mengatur anak-anak untuk berbaris dengan rapi dan sesuai dengan kelas masing-masing serta tak lupa juga anak-anak menyanyikan beberapa lagu, kemudian mengucapkan salam dan masuk kelas secara berurut. Selanjutnya guru membuka proses pembelajaran dengan mengucapkan salam, setelah itu anak-anak bernyanyi beberapa lagu.

Sebelum memasuki proses pembelajaran anak-anak melakukan aktifitas tanya jawab bersama guru mengenai pelajaran sebelumnya. Pada kegiatan inti pertemuan I dalam meningkatkan kemampuan motorik halus anak, guru melakukan kegiatan motorik awal yang biasa dilakukan pada tiap paginya dalam kelas. Guru menjelaskan tentang tema yang dibawakan yaitu tema binatang/binatang yang hidup di laut/gurita. Guru mengadakan tanya jawab akan tema yang telah dijelaskan kepada anak-anak. Setelah memberikan apersepsi dan tanya jawab dengan anak, guru menjelaskan mengenai tugas yang akan dilakukan. Pertama adalah guru memperlihatkan boneka yang telah dibuatnya, guru menjelaskan langkah-langkah dalam membuat boneka, guru memberikan alat dan bahan pada masing-masing anak untuk membuat boneka menyerupai gurita dan guru memberikan bimbingan pada anak-anak yang masih kesusahan dalam membuat boneka.

Selanjutnyan masuk pada kegiatan akhir dimana guru mempersilahkan anak-anak untuk duduk kembali dan mengarahkan anak untuk mencuci tangan sebelum makan. Kemudian, 
masuk pada kegiatan makan bersama, sebelum kegiatan makan bersama dimulai guru membimbing anak untuk membaca doa sebelum makan. Setelah anak selesai makan guru membimbing anak berdoa sesudah makan dan mempersilahkan anak untuk bermain diluar ruangan. Selanjutnya, anak masuk kedalam ruangan untuk bersiap pulang, sebelum jam pelajaran ditutup, guru mengajak anak untuk membuat kesimpulan tentang kegiatan yang telah dilakukan yaitu menceritakan tentang kegiatan apa yang telah dilakukan. Setelah itu guru memberikan informasi tentang kegiatan yang akan dilakukan besok, kemudian guru mempersiapkan anak-anak untuk membaca doa keluar kelas dan doa keselamatan dunia akhirat dan lain-lain serta mengucapkan salam.

Pelaksanaan tindakan siklus I pertemuan IV dilaksanakan dengan kegiatan inti guru mengatur anak-anak untuk berbaris dengan rapi dan sesuai dengan kelas masing-masing serta tak lupa juga anak-anak menyanyikan beberapa lagu, kemudian mengucapkan salam dan masuk kelas secara berurut. Selanjutnya guru membuka proses pembelajaran dengan mengucapkan salam, setelah itu anak-anak bernyanyi beberapa lagu.

Sebelum memasuki proses pembelajaran anak-anak melakukan aktifitas tanya jawab bersama guru mengenai pelajaran sebelumnya. Pada kegiatan inti pertemuan I dalam meningkatkan kemampuan motorik halus anak, guru melakukan kegiatan motorik awal yang biasa dilakukan pada tiap paginya dalam kelas. Guru menjelaskan tentang tema yang dibawakan yaitu tema binatang/binatang yang hidup di laut/kuda laut. Guru mengadakan tanya jawab akan tema yang telah dijelaskan kepada anakanak. Setelah memberikan apersepsi dan tanya jawab dengan anak, guru menjelaskan mengenai tugas yang akan dilakukan. Pertama adalah guru memperlihatkan boneka yang telah dibuatnya, guru menjelaskan langkah-langkah dalam membuat boneka, guru memberikan alat dan bahan pada masing-masing anak untuk membuat boneka menyerupai kuda laut dan guru memberikan bimbingan pada anak-anak yang masih kesusahan dalam membuat boneka.

Selanjutnyan masuk pada kegiatan akhir dimana guru mempersilahkan anak-anak untuk duduk kembali dan mengarahkan anak untuk mencuci tangan sebelum makan. Kemudian, masuk pada kegiatan makan bersama, sebelum kegiatan makan bersama dimulai guru membimbing anak untuk membaca doa sebelum makan. Setelah anak selesai makan guru membimbing anak berdoa sesudah makan dan mempersilahkan anak untuk bermain diluar ruangan. Selanjutnya, anak masuk kedalam ruangan untuk bersiap pulang, sebelum jam pelajaran ditutup, guru mengajak anak untuk membuat kesimpulan tentang kegiatan yang telah dilakukan yaitu menceritakan tentang kegiatan apa yang telah dilakukan. Setelah itu guru memberikan informasi tentang kegiatan yang akan dilakukan besok, kemudian guru mempersiapkan anak-anak untuk membaca doa keluar kelas dan doa keselamatan dunia akhirat dan lain-lain serta mengucapkan salam.

Selama proses pembelajaran berlangsung, guru sebagai observer mengamati jalannya pembelajaran dengan menggunakan lembar observasi untuk guru dan lembar observasi untuk anak. Kegiatan observasi dilakukan bersamaan dengan pelaksanaan tindakan untuk setiap pertemuan pada siklus I.

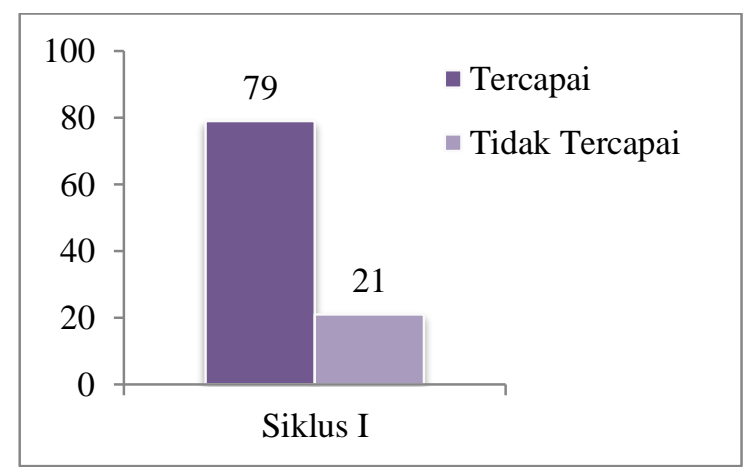

Gambar 1. Diagram Hasil Analisis Aktivitas Mengajar Guru Siklus I

Hasil analisis observasi guru sesuai dengan lembar observasi sebanyak 14 aspek. Pada siklus I tercapai 11 aspek (79\%) diantaranya: (1) guru membuka pembelajaran dengan kegiatan imtaq, (2) guru melaksanakan kegiatan pembelajaran sesuai RPPH, (3) guru melakukan kegiatan apersepsi berdasarkan tema dan subtema (4) guru menyiapkan media pembelajaran dalam kegiatan membuat boneka, (5) guru menjelaskan langkah-langkah dalam kegiatan membuat boneka, (6) guru membimbing anak dalam kegiatan membuat boneka, (7) guru meminta anak untuk menggunting kain flannel sesuai pola gambar binatang yang hidup di laut, (8) guru meminta anak untuk menempelkan sebagian sisi tepi pola gambar binatang yang hidup di laut dengan menggunakan lem, (9) guru meminta anak untuk mengisi tubuh binatang dengan dakron hingga penuh dan empuk kemudian melem semua bagian tepi yang belum tertutup, (10) guru meminta anak untuk menempelkan bagian- 
bagian tubuh binatang yang belum lengkap, (11) guru mengadakan tanya jawab mengenai kegiatan yang telah dilakukan. Sedangkan yang tidak tercapai sebanyak 3 aspek (21\%) diantaranya: (1), guru menjelaskan tujuan pembelajaran (2) guru memberikan penghargaan kepada anak yang dapat menyelesaikan tugasnya tanpa bantuan guru, (3) guru memberikan kesimpulan terhadap kegiatan yang telah dilalakukan.

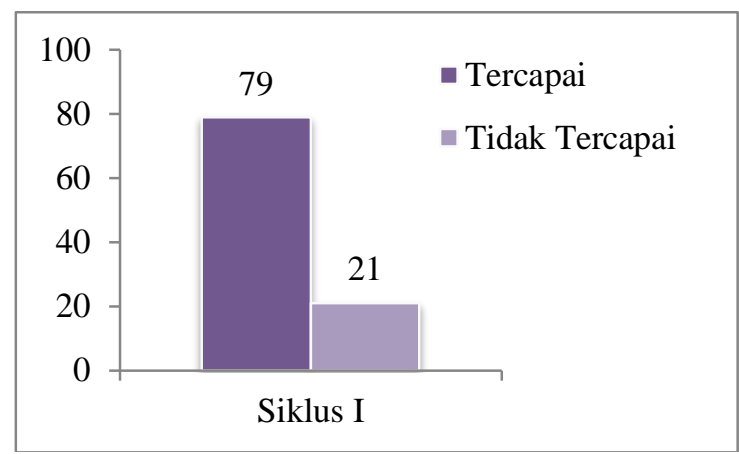

Gambar 2. Diagram Hasil Analisis Aktivitas Belajar Anak Didik Siklus I

Hasil analisis observasi anak sesuai dengan lembar observasi sebanyak 14 aspek. Pada siklus I tercapai 11 aspek (79\%) diantaranya: (1) anak mengawali pembelajaran dengan kegiatan imtaq, (2), anak mengikuti kegiatan pembelajaran sesuai RPPH, (3) anak dapat menjawab kegiatan apersepsi berdasarkan tema dan subtema pembelajaran, (4) anak memperoleh media pembelajaran dalam kegiatan membuat boneka, (5) anak memperhatikan langkah-langkah dalam kegiatan membuat boneka, (6) anak mendapat bimbingan dalam kegiatan membuat boneka, (7) anak dapat menggunting kain flannel sesuai pola gambar binatang yang hidup di laut, (8) anak dapat menempelkan sebagian sisi tepi pola gambar binatang yang hidup di laut dengan menggunakan lem, (9) anak dapat mengisi tubuh binatang dengan dakron hingga penuh dan empuk kemudian melem semua bagian tepi yang belum tertutup, (10) anak dapat menempelkan bagian-bagian tubuh binatang yang belum lengkap, (11) anak dapat menjawab kegiatan tanya jawab mengenai kegiatan yang telah dilakukan. Sedangkan yang tidak tercapai sebanyak 3 aspek (21\%) diantaranya: (1) anak mendengarkan tujuan pembelajaran yang disampaikan guru, (2) anak memperoleh penghargaan dari guru karena menyelesaikan tugasnya tanpa bantuan guru, (3) anak memperhatikan kesimpulan terhadap kegiatan yang telah dilalakukan.
Tabel 2. Nilai Klasikal pada Siklus I

\begin{tabular}{lcc}
\hline \multicolumn{1}{c}{ Kategori } & Jumlah & $\mathbf{( \% )}$ \\
\hline $\begin{array}{l}\text { Berkembang Sangat } \\
\text { Baik }\end{array}$ & 6 & $40 \%$ \\
\hline $\begin{array}{l}\text { Berkembang Sesuai } \\
\text { Harapan }\end{array}$ & 5 & $33 \%$ \\
\hline Mulai Berkembang & 4 & $27 \%$ \\
\hline Belum Berkembang & 0 & 0 \\
\hline \multicolumn{1}{c}{ Jumlah } & 15 & $100 \%$ \\
\hline
\end{tabular}

Berdasarkan hasil yang diperoleh pada tabel 2 terlihat bahwa secara klasikal kegiatan meningkatkan kemampuan motorik halus melalui kegiatan membuat boneka sebagian besar anak sudah dapat melaksanakan kegiatan dengan baik yaitu $73 \%$ anak memperoleh nilai BSB dan BSH, sehingga dapat dikatakan dengan kegiatan membuat boneka terjadi peningkatan pada kemampuan motorik halus atau kreativitas anak. Hal ini sejalan dengan penelitian yang dilakukan oleh (Agustin, 2017) bahwa ada pengaruh kegiatan membuat boneka jerami terhadap perkembangan kreativitas dan sosial emosional pada anak. Namun pada penelitian ini indikator kinerja yang ditetapkan sebesar $85 \%$ belum tercapai oleh anak yang memperoleh nilai BSB dan BSH. Oleh karena itu, guru dan peneliti mendiskusikan kekurangan-kekurangan apa saja yang terdapat pada pelaksanaan tindakan siklus I untuk kemudian diperbaiki dan dilaksanakan pada siklus II. Dari hasil observasi, maka hal yang harus diperbaiki adalah peneliti harus segera melaksanakan persiapan dan perencanaan dengan matang, segala yang dilakukan pada tindakan siklus I harus dicermati dan diperbaiki kembali.

Pelaksanaan tindakan siklus II pertemuan I dilaksanakan dengan kegiatan inti guru mengatur anak-anak untuk berbaris dengan rapi dan sesuai dengan kelas masing-masing serta tak lupa juga anak-anak menyanyikan beberapa lagu, kemudian mengucapkan salam dan masuk kelas secara berurut. Selanjutnya guru membuka proses pembelajaran dengan mengucapkan salam, setelah itu anak-anak bernyanyi beberapa lagu.

Sebelum memasuki proses pembelajaran anak-anak melakukan aktifitas tanya jawab bersama guru mengenai pelajaran sebelumnya. Pada kegiatan inti pertemuan I dalam meningkatkan kemampuan motorik halus anak, guru melakukan kegiatan motorik awal yang biasa dilakukan pada tiap paginya dalam kelas. Guru menjelaskan tentang tema yang dibawakan yaitu tema binatang/binatang yang hidup di 
darat/bebek. Guru mengadakan tanya jawab akan tema yang telah dijelaskan kepada anakanak. Setelah memberikan apersepsi dan tanya jawab dengan anak, guru menjelaskan mengenai tugas yang akan dilakukan. Pertama adalah guru memperlihatkan boneka yang telah dibuatnya, guru menjelaskan langkah-langkah dalam membuat boneka, guru memberikan alat dan bahan pada masing-masing anak untuk membuat boneka menyerupai bebek dan guru memberikan bimbingan pada anak-anak yang masih kesusahan dalam membuat boneka.

Selanjutnyan masuk pada kegiatan akhir dimana guru mempersilahkan anak-anak untuk duduk kembali dan mengarahkan anak untuk mencuci tangan sebelum makan. Kemudian, masuk pada kegiatan makan bersama, sebelum kegiatan makan bersama dimulai guru membimbing anak untuk membaca doa sebelum makan. Setelah anak selesai makan guru membimbing anak berdoa sesudah makan dan mempersilahkan anak untuk bermain diluar ruangan. Selanjutnya, anak masuk kedalam ruangan untuk bersiap pulang, sebelum jam pelajaran ditutup, guru mengajak anak untuk membuat kesimpulan tentang kegiatan yang telah dilakukan yaitu menceritakan tentang kegiatan apa yang telah dilakukan. Setelah itu guru memberikan informasi tentang kegiatan yang akan dilakukan besok, kemudian guru mempersiapkan anak-anak untuk membaca doa keluar kelas dan doa keselamatan dunia akhirat dan lain-lain serta mengucapkan salam.

Pelaksanaan tindakan siklus II pertemuan II dilaksanakan dengan kegiatan inti guru mengatur anak-anak untuk berbaris dengan rapi dan sesuai dengan kelas masing-masing serta tak lupa juga anak-anak menyanyikan beberapa lagu, kemudian mengucapkan salam dan masuk kelas secara berurut. Selanjutnya guru membuka proses pembelajaran dengan mengucapkan salam, setelah itu anak-anak bernyanyi beberapa lagu.

Sebelum memasuki proses pembelajaran anak-anak melakukan aktifitas tanya jawab bersama guru mengenai pelajaran sebelumnya. Pada kegiatan inti pertemuan I dalam meningkatkan kemampuan motorik halus anak, guru melakukan kegiatan motorik awal yang biasa dilakukan pada tiap paginya dalam kelas. Guru menjelaskan tentang tema yang dibawakan yaitu tema binatang/binatang yang hidup di darat/sapi. Guru mengadakan tanya jawab akan tema yang telah dijelaskan kepada anak-anak. Setelah memberikan apersepsi dan tanya jawab dengan anak, guru menjelaskan mengenai tugas yang akan dilakukan. Pertama adalah guru memperlihatkan boneka yang telah dibuatnya, guru menjelaskan langkah-langkah dalam membuat boneka, guru memberikan alat dan bahan pada masing-masing anak untuk membuat boneka menyerupai sapi dan guru memberikan bimbingan pada anak-anak yang masih kesusahan dalam membuat boneka.

Selanjutnyan masuk pada kegiatan akhir dimana guru mempersilahkan anak-anak untuk duduk kembali dan mengarahkan anak untuk mencuci tangan sebelum makan. Kemudian, masuk pada kegiatan makan bersama, sebelum kegiatan makan bersama dimulai guru membimbing anak untuk membaca doa sebelum makan. Setelah anak selesai makan guru membimbing anak berdoa sesudah makan dan mempersilahkan anak untuk bermain diluar ruangan. Selanjutnya, anak masuk kedalam ruangan untuk bersiap pulang, sebelum jam pelajaran ditutup, guru mengajak anak untuk membuat kesimpulan tentang kegiatan yang telah dilakukan yaitu menceritakan tentang kegiatan apa yang telah dilakukan. Setelah itu guru memberikan informasi tentang kegiatan yang akan dilakukan besok, kemudian guru mempersiapkan anak-anak untuk membaca doa keluar kelas dan doa keselamatan dunia akhirat dan lain-lain serta mengucapkan salam.

Pelaksanaan tindakan siklus II pertemuan III dilaksanakan dengan kegiatan inti guru mengatur anak-anak untuk berbaris dengan rapi dan sesuai dengan kelas masing-masing serta tak lupa juga anak-anak menyanyikan beberapa lagu, kemudian mengucapkan salam dan masuk kelas secara berurut. Selanjutnya guru membuka proses pembelajaran dengan mengucapkan salam, setelah itu anak-anak bernyanyi beberapa lagu.

Sebelum memasuki proses pembelajaran anak-anak melakukan aktifitas tanya jawab bersama guru mengenai pelajaran sebelumnya. Pada kegiatan inti pertemuan I dalam meningkatkan kemampuan motorik halus anak, guru melakukan kegiatan motorik awal yang biasa dilakukan pada tiap paginya dalam kelas. Guru menjelaskan tentang tema yang dibawakan yaitu tema binatang/binatang yang hidup di darat/kelinci. Guru mengadakan tanya jawab akan tema yang telah dijelaskan kepada anakanak. Setelah memberikan apersepsi dan tanya jawab dengan anak, guru menjelaskan mengenai tugas yang akan dilakukan. Pertama adalah guru memperlihatkan boneka yang telah dibuatnya, guru menjelaskan langkah-langkah dalam membuat boneka, guru memberikan alat dan 
bahan pada masing-masing anak untuk membuat boneka menyerupai kelinci dan guru memberikan bimbingan pada anak-anak yang masih kesusahan dalam membuat boneka.

Selanjutnyan masuk pada kegiatan akhir dimana guru mempersilahkan anak-anak untuk duduk kembali dan mengarahkan anak untuk mencuci tangan sebelum makan. Kemudian, masuk pada kegiatan makan bersama, sebelum kegiatan makan bersama dimulai guru membimbing anak untuk membaca doa sebelum makan. Setelah anak selesai makan guru membimbing anak berdoa sesudah makan dan mempersilahkan anak untuk bermain diluar ruangan. Selanjutnya, anak masuk kedalam ruangan untuk bersiap pulang, sebelum jam pelajaran ditutup, guru mengajak anak untuk membuat kesimpulan tentang kegiatan yang telah dilakukan yaitu menceritakan tentang kegiatan apa yang telah dilakukan. Setelah itu guru memberikan informasi tentang kegiatan yang akan dilakukan besok, kemudian guru mempersiapkan anak-anak untuk membaca doa keluar kelas dan doa keselamatan dunia akhirat dan lain-lain serta mengucapkan salam.

Pelaksanaan tindakan siklus II pertemuan IV dilaksanakan dengan kegiatan inti guru mengatur anak-anak untuk berbaris dengan rapi dan sesuai dengan kelas masing-masing serta tak lupa juga anak-anak menyanyikan beberapa lagu, kemudian mengucapkan salam dan masuk kelas secara berurut. Selanjutnya guru membuka proses pembelajaran dengan mengucapkan salam, setelah itu anak-anak bernyanyi beberapa lagu.

Sebelum memasuki proses pembelajaran anak-anak melakukan aktifitas tanya jawab bersama guru mengenai pelajaran sebelumnya. Pada kegiatan inti pertemuan I dalam meningkatkan kemampuan motorik halus anak, guru melakukan kegiatan motorik awal yang biasa dilakukan pada tiap paginya dalam kelas. Guru menjelaskan tentang tema yang dibawakan yaitu tema binatang/binatang yang hidup di darat/kucing. Guru mengadakan tanya jawab akan tema yang telah dijelaskan kepada anakanak. Setelah memberikan apersepsi dan tanya jawab dengan anak, guru menjelaskan mengenai tugas yang akan dilakukan. Pertama adalah guru memperlihatkan boneka yang telah dibuatnya, guru menjelaskan langkah-langkah dalam membuat boneka, guru memberikan alat dan bahan pada masing-masing anak untuk membuat boneka menyerupai kucing dan guru memberikan bimbingan pada anak-anak yang masih kesusahan dalam membuat boneka.
Selanjutnyan masuk pada kegiatan akhir dimana guru mempersilahkan anak-anak untuk duduk kembali dan mengarahkan anak untuk mencuci tangan sebelum makan. Kemudian, masuk pada kegiatan makan bersama, sebelum kegiatan makan bersama dimulai guru membimbing anak untuk membaca doa sebelum makan. Setelah anak selesai makan guru membimbing anak berdoa sesudah makan dan mempersilahkan anak untuk bermain diluar ruangan. Selanjutnya, anak masuk kedalam ruangan untuk bersiap pulang, sebelum jam pelajaran ditutup, guru mengajak anak untuk membuat kesimpulan tentang kegiatan yang telah dilakukan yaitu menceritakan tentang kegiatan apa yang telah dilakukan. Setelah itu guru memberikan informasi tentang kegiatan yang akan dilakukan besok, kemudian guru mempersiapkan anak-anak untuk membaca doa keluar kelas dan doa keselamatan dunia akhirat dan lain-lain serta mengucapkan salam.

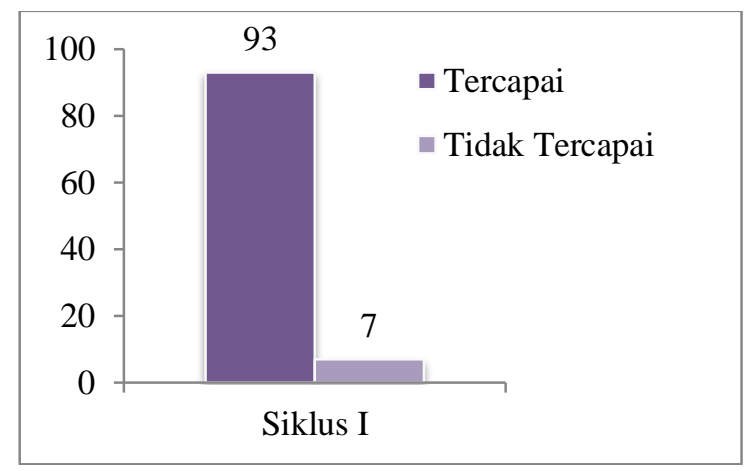

Gambar 3. Diagram Hasil Analisis Aktivitas Mengajar Guru Siklus II

Hasil analisis observasi guru sesuai dengan lembar observasi sebanyak 14 aspek. Pada siklus II tercapai 13 aspek (93\%) diantaranya: (1) guru membuka pembelajaran dengan kegiatan imtaq, (2) guru melaksanakan kegiatan pembelajaran sesuai RPPH, (3) guru melakukan kegiatan apersepsi berdasarkan tema dan subtema (4) guru menyiapkan media pembelajaran dalam kegiatan membuat boneka, (5) guru menjelaskan langkah-langkah dalam kegiatan membuat boneka, (6) guru membimbing anak dalam kegiatan membuat boneka, (7) guru meminta anak untuk menggunting kain flannel sesuai pola gambar binatang yang hidup di laut, (8) guru meminta anak untuk menempelkan sebagian sisi tepi pola gambar binatang yang hidup di laut dengan menggunakan lem, (9) guru meminta anak untuk mengisi tubuh binatang dengan dakron hingga penuh dan empuk kemudian melem semua bagian tepi yang belum tertutup, (10) 
guru meminta anak untuk menempelkan bagianbagian tubuh binatang yang belum lengkap, (11) guru mengadakan tanya jawab mengenai kegiatan yang telah dilakukan, (12) guru memberikan penghargaan kepada anak yang dapat menyelesaikan tugasnya tanpa bantuan guru, (13) guru memberikan kesimpulan terhadap kegiatan yang telah dilakukan. Sedangkan yang tidak tercapai sebanyak 1 aspek (7\%) yaitu: (1) guru menjelaskan tujuan pembelajaran.

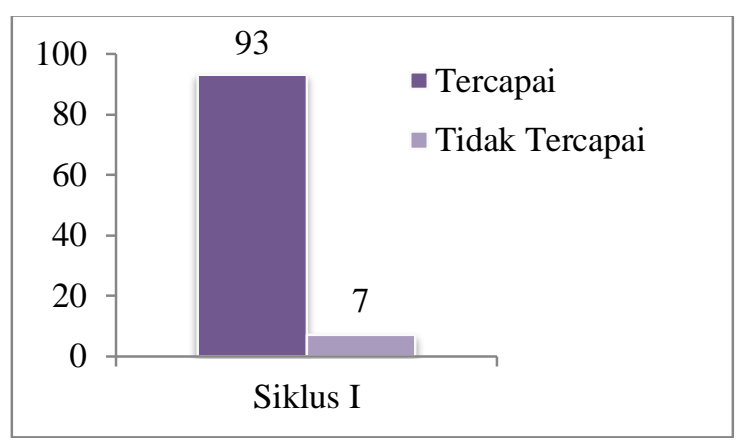

Gambar 1. Diagram Hasil Analisis Aktivitas Belajar Anak Didik Siklus II

Hasil analisis observasi anak sesuai dengan lembar observasi sebanyak 14 aspek. Pada siklus II tercapai 13 aspek (93\%) diantaranya: (1) anak mengawali pembelajaran dengan kegiatan imtaq, (2) anak mengikuti kegiatan pembelajaran sesuai RPPH, (3) anak dapat menjawab kegiatan apersepsi berdasarkan tema dan subtema pembelajaran, (4) anak memperoleh media pembelajaran dalam kegiatan membuat boneka, (5) anak memperhatikan langkah-langkah dalam kegiatan membuat boneka, (6) anak mendapat bimbingan dalam kegiatan membuat boneka, (7) anak dapat menggunting kain flannel sesuai pola gambar binatang yang hidup di laut, (8) anak dapat menempelkan sebagian sisi tepi pola gambar binatang yang hidup di laut dengan menggunakan lem, (9) anak dapat mengisi tubuh binatang dengan dakron hingga penuh dan empuk kemudian melem semua bagian tepi yang belum tertutup, (10) anak dapat menempelkan bagian-bagian tubuh binatang yang belum lengkap, (11) anak dapat menjawab kegiatan tanya jawab mengenai kegiatan yang telah dilakukan, (12) anak memperoleh penghargaan dari guru karena menyelesaikan tugasnya tanpa bantuan guru, (13) anak memperhatikan kesimpulan terhadap kegiatan yang telah dilalakukan. Sedangkan yang tidak tercapai sebanyak 1 aspek (7\%) yaitu: (1) anak mendengarkan tujuan pembelajaran yang disampaikan guru.

Tabel 3. Nilai Klasikal pada Siklus II

\begin{tabular}{lcc}
\hline \multicolumn{1}{c}{ Kategori } & Jumlah & $\mathbf{( \% )}$ \\
\hline $\begin{array}{l}\text { Berkembang Sangat } \\
\text { Baik }\end{array}$ & 7 & $47 \%$ \\
\hline $\begin{array}{l}\text { Berkembang Sesuai } \\
\text { Harapan }\end{array}$ & 6 & $40 \%$ \\
\hline Mulai Berkembang & 2 & $13 \%$ \\
\hline Belum Berkembang & 0 & 0 \\
\hline \multicolumn{1}{c}{ Jumlah } & 15 & $100 \%$ \\
\hline
\end{tabular}

Berdasarkan data hasil perolehan nilai anak didik yang ditampilkan pada tabel 3, maka dapat disimpulkan bahwa secara klasikal perolehan nilai anak didik dalam kegiatan meningkatkan kemampuan motorik halus melalui kegiatan membuat boneka mengalami peningkatan, karena tingkat keberhasilan anak didik yaitu sebesar $87 \%$ memperoleh nilai BSH dan BSB, dapat dikatakan bahwa sebagian besar anak didik dipandang telah mampu menyelesaikan tugas-tugas yang telah ditetapkan sesuai dengan indikator penilaian dalam penelitian ini khususnya dalam pelaksanaan tindakan siklus II. Hasil penelitian ini sejalan dengan penelitian yang dilakukan oleh (Kristianingsih, 2017) bahwa dengan kegiatan membuat boneka kreativitas anak dapat ditingkatkan.

Jika dilihat dari pemahaman anak didik mulai dari pelaksanaan siklus I sebesar 73\% jika dibandingkan pada tahapan observasi awal atau prasiklus penelitian yang hanya mencapai $47 \%$ dan pada tindakan siklus II mencapai persentase sebesar $87 \%$, maka hal tersebut menunjukkan hasil yang lebih baik dari sebelumnya, karena indikator kinerja yang ditetapkan telah tercapai yaitu minimal $85 \%$ sehigga peneliti dan guru sepakat bahwa penelitian ini dapat dihentikan sampai pada siklus II. Hal ini sejalan dengan penelitian yang dilakukan oleh peneliti-peneliti sebelumnya yang juga menggunaan media boneka untuk meningkatkan kemampuan motorik halus anak, seperti meningkatkan keterampilan, kreativitas, maupun kemampuan berbicara anak, diantarannya penelitian yang dilakukan oleh (Hasanah, Harmawati, \& Hidayat, 2019) yang menggunakan media boneka jari (finger puppets) untuk meningkatkan kemampuan berbicara anak. Kemudian penelitian yang dilakukan oleh (Sari, Hamid, \& Sutini, 2016) menyimpukan bahwa keterampilan sosial anak meningkat setelah menggunaan media boneka jari dalam kegiatan pembelajaran. 


\section{KESIMPULAN DAN SARAN Kesimpulan}

Berdasarkan hasil observasi dan hasil penelitian aktivitas anak yang telah dilakukan, maka dapat ditarik kesimpulan sebagai berikut: (1) observasi awal anak didik yang memperoleh nilai ketuntasan secara klasikal $47 \%$ yaitu 7 orang yang mendapat nilai (***) atau Berkembang Sesuai Harapan (BSH) dan (****) atau Berkembang Sangat Baik (BSB). Pada siklus I mencapai $73 \%$ yaitu 11 orang anak yang mendapat nilai (***) atau Berkembang Sesuai Harapan dan (****) atau Berkembang Sangat Baik (BSB). Selanjutnya pada siklus II diperoleh nilai ketuntasan secara klasikal $87 \%$ yaitu 13 orang anak didik yang mendapat nilai (****) atau Berkembang Sangat Baik (BSB) dan nilai (***) atau Berkembang Sesuai Harapan (BSH); (2) hasil observasi aktivitas mengajar guru pada sikluls I memperoleh persentase keberhasilan sebesar $79 \%$ dan hasil observasi aktivitas belajar anak didik pada siklus I memperoleh presentase keberhasilan 79\%. Selanjutnya pada siklus II aktivitas mengajar guru memperoleh presentase keberhasilan sebesar $93 \%$ dan hasil aktivitas observasi aktivitas belajar anak sebesar $93 \%$.

\section{Saran}

Setelah melaksanakan tindakan penelitian maka peneliti menyarankan hal-hal diantaranya dalam pelaksanaan pembelajaran maka hendaknya mempertimbangkan materi, media, dan strategi yang tepat untuk anak didik dan guru dituntut untuk selalu kreatif dan inovatif dalam melaksanakan kegiatan-kegiatan yang dapat meningkatkan potensi anak didik.

\section{DAFTAR PUSTAKA}

Agustin, L. D. (2017). Pengaruh Aktivitas Membuat Boneka Jerami Terhadap Perkembangan Kreativitas dan Sosial Emosional Anak Kelompok B. Jurnal PG-PAUD Trunojoyo, 4(1), 1-81. https://doi.org/10.21107/pgpaudtrunojoy o.v4i1.3539

Angraeni, N., Arvyaty, \& Salim. (2018). Meningkatkan Kemampuan Anak Melalui Media Papan Flanel. Jurnal Riset Golden Age PAUD UHO 1(3), 190-194.

http://dx.doi.org/10.36709/jrga.v1i3.910 5

Darmiatun, S. \& Mayar, F. (2020). Meningkatkan Kemampuan Motorik Halus Anak Melalui Kolase Dengan
Menggunkan Bahan Bekas pada Anak Usia Dini. Jurnal Obsesi, 4(1), 247-257. DOI: $10.31004 /$ obsesi.v4i1.327

Hasanah, D. Harmawati, D. \& Hidayat, A. K. (2019). Meningkatkan Kemampuan Berbicara Anak Melalui Kegiatan Bercerita Berbantu Media Finger Puppet pada Anak TK Kelompok B. Musamu Journal of Primary Education, 2(1), 3237.

https://doi.org/10.35724/musjpe.v2i1.20 46

Kristianingsih, D. (2017). Upaya Meningkatkan Kreativitas Anak Melalui Kegiatan Membuat Boneka Sendok di PPT Mutiara Bunda Surabaya. Jurnal PAUD Teratai, 6(1), 1-4.

Kusumaningtyas, L. E. (2016). Bermain dalam Rangka Mengembangkan Motorik pada Anak Usia Dini. INDRIA Jurnal Ilmiah Pendidikan PraSekolah Dan Sekolah Awal, 1(1), 32-41.

Nurhasanah. Malik, H. A. \& Alaby, M. A. (2019). Upaya Meningkatkan Motorik Halus Melalui Permainan Membuat Boneka Kertas. Prosiding Seminar Nasional Pendidikan STKIP Kusuma Negara. Bogor; 6 oktober 2019. 1-7.

Nurlila, R. U. \& Fua, J. L. (2015). Perbedaan Perkembangan Motorik Kasar dan Halus yang Mendapat Asi Eksklusif dan Non Asi Eksklusif di Desa Penggotu Kecamatan Lambandia Kabupaten Kolaka Tahun 2013. Shautut Tarbiyah, 33(19), 112-129.

Pura, D. N. \& Asnawati. (2019). Perkembangan Motorik Halus Anak Usia Dini Melalui Kolase Media Serutan Pensil. Jurnal Ilmiah Potensia, 4(2), 131-140.

Romlah. (2017). Pengaruh Motorik Halus dan Motorik Kasar terhadap Perkembangan Kreativitas Anak Usia Dini. TADRIS: Jurnal Keguruan dan Ilmu Tarbiyah, 2(2), 131-137. https://doi.org/10.24042/tadris.v2i2.231 4

Sari, R. I. Hamid, S. I. \& Sutini, A. (2016). Meningkatkan Keterampilan Sosial Anak Usia Dini Melalui Media Boneka Jari. Cakrawala Dini: Jurnal 
Pendidikan Anak Usia Dini, 7(1), 1-10. https://doi.org/10.17509/cd.v7i1.10543

Widianingsih, E. (2012). Pendidikan Karakter Pada Taman Kanak Kanak Kenapa Tidak?. Cakrawala Dini, 3(2). 1-11. https://doi.org/10.17509/cd.v3i2.10335 